\title{
COLOURED MEMBERS OF THE BAHAMIAN HOUSE OF ASSEMBLY IN THE
}

\section{NINETEENTH CENTURY}

\author{
Rosalyn Themistocleous
}

\begin{abstract}
This article focuses on some little known 'coloured' members of the House of Assembly of the nineteenth century. The position of the Bahamians of mixed race is discussed, particularly vis-à-vis the white Nassauvian elite. Their achievements are noted, but the limitations of their political careers are emphasised. These men were, in essence, politically and socially ambitious individuals, who did not seek to represent the lower classes or black Bahamians. Moreover, party organisation was not yet a feature of the Bahamian political system, except during a period of religious turmoil in mid-century when denominational adherence was the grouping factor. The coloured representatives were generally pro-Government and pro-Established Church.
\end{abstract}

\section{INTRODUCTION}

In the Post-Emancipation era of Bahamian history a small but significant number of coloured ${ }^{1}$ Bahamians were elected to the House of Assembly. They achieved this despite the prevalent racism and political and socio-economic dominance of the former slave-owners and their descendents. Colour was of defining importance in nineteenth century Nassau society. The main distinction in slave society had been between slave and free; in the reconstructed society race and colour came to be the most important consideration. The white Bahamian elite had to employ a number of strategies, political, socio-economic and judicial, to ensure its continued dominance. Land remained in the hands of the former slaver-holders, while the former slaves became sharecroppers or tenants, eking out a bare living from the soil. The credit and truck systems, rather than a wage labour system, were employed in the majority of industries; these were coercive labour systems that only benefited Nassau merchants.

Having subjected most of the lower classes to a state of economic dependency, the white Nassauvians also controlled most of the seats in the House of Assembly and the Councils. This is of particular significance in a colony still ruled under the Old Representative system, where the local elite was allowed a large degree of self-government. In The Bahamas local legislation specified that decisions must be those of the Governor-in-Council and the Imperial Government acknowledged the established usage whereby the Governor acted in accordance with the Council's advice. The Council separated into two bodies in 1841: the Executive Council acted as this advisory body, while the Legislative Council was the Upper House of the Legislature. There were ex-officio and unofficial members, appointed by the Governor, in both bodies. The Colonial Secretary, Attorney-General and Receiver-General sat in the Executive Council in the second half of the century, forming the ex-officio element. The white Bahamians monopolised the non-official seats on the Executive and Legislative Councils. Most of the unofficial members, who formed a majority in the Executive Council, were members of the elected House 
of Assembly or the Legislative Council. Hence the Legislature had some control over the Executive. Moreover, the House of Assembly had the 'power of the purse', that is the sole right to introduce money bills and initiate taxation. This was a potent weapon that could be used by the local elite against the Governor. The electoral system, which retained open voting, inequitable constituencies, a franchise weighted in favour of the propertied classes and plural voting, ensured the white Nassauvians controlled most of the twenty-nine seats in the House. The widespread bribery and corruption and the fact that the lower classes failed to organise themselves politically particularly facilitated white political dominance. Besides many electors were in debt to Nassau merchants so, in an open voting system, were unlikely to vote against an approved candidate. In New Providence there was always a cross-section of colours and classes included on the electoral registers and these voters often had coloured or black middle class candidates to vote for. But in the Out Islands voters, with few exceptions, had to choose from among the white candidates from Nassau as islanders could not afford to spend the time to attend the House meetings, members not being paid a salary. The result was that, as Stipendiary Magistrate L.D. Powles (1888) so accurately recorded, "the House of Assembly is little less than a family gathering of Nassau whites, nearly all of whom are related to each other, either by blood or marriage" (p.41). There was a prevailing assumption by the whites that their leadership was indispensable to good governance.

Seen in this context, the dent into the white power monopoly by a few Bahamians of mixed race is quite an achievement. Certainly, a degree of co-optation of the coloured middle class was tolerated by the white elite. The coloureds were encouraged to adopt elitist values and attitudes to law and order and social institutions. Of course, the paler the coloureds were (near-white or high yaller in local parlance) the more chance they had of being tolerated. Moreover, it was noted by several visitors to the islands that a good many "so called white families" in Nassau were not of pure white blood, but were fair enough to pass for white in Europe and were considered white in Nassau. L.D. Powles (1888) described this confusing state of affairs thus: "Where the line that separates the white man, so-called, from the coloured is drawn in Nassau, must ever remain a mystery to the stranger" (p.121).

The successful coloured politicians of the nineteenth century had acquired middle class status from their positions as relatively wealthy, small businessmen or as professional men. As Raymond Smith (1988) notes, after 1838, "classes seemed to be defined in terms of race" in the West Indies (p.93). Thus the term 'coloured middle class' is the commonly used term for the intermediate group between the white elite and the labouring and under classes, even though the class also contained some blacks and whites. The class is also defined in terms of occupation and values and outlooks. The middle class is taken to include those in the professional occupations and public service, craftsmen, small businessmen, printers and journalists, managers and supervisors and senior clerical workers. As for outlook, Gail Saunders (1990) sums up the Bahamian position thus: "Aspiring coloureds attempted to obtain a good education, secure good jobs, own land, enter politics and attend the right churches" (pp. 2-3). They sought respectability, if anything assuming mores of stricter morality than the white elite.

The coloured middles classes of Nassau had to accommodate themselves to the socioracial dividing lines that existed in the town. They lived predominantly in Delancy Town. The Established Church was the preference of most coloureds, probably an indication of 
identification with British culture and tradition, but they were generally assigned to the side aisles. Coloured Methodists usually worshipped at Ebenezer Chapel in the eastern suburbs, the congregation at Trinity Methodist Chapel exhibiting a desire to remain exclusively white. Some coloured boys were able to get a secondary education at the Boys Central School or the Anglican Nassau Grammar School. Further education was uncommon unless parents were wealthy enough to send their sons abroad (but this was true for whites too). Whites, naturally, found more opportunity for clerkships with Bay Street merchants and law firms, but a number of coloureds did overcome these barriers. Social discrimination, though, continued throughout the century. Whites worked with and sometimes showed respect to coloureds, but did not invite them to their homes. The coloureds thus became quite a closely-knit group. There were exceptions to this social prejudice, notably the acceptance of Thomas Mathews and William Armbrister, who probably "passed" for white. The practice adopted by most coloureds was to accept their position in the social hierarchy. The mulatto exhibited no pride in his African blood and tried to emulate and, if possible, join white society. The ideal was to 'marry up' to produce offspring of a lighter complexion and they treated anyone a shade darker than themselves with the same prejudices that they experienced from the whites. The coloured members of the Bahamian Assembly were essentially ambitious individuals and did little to further legislation to aid the coloured and black population at large.

\section{LEGAL CHANGES IN 1833 AND EARLY SUCCESSES FOR THE COLOURED CLASS}

The 1807 Act ( 47 Geo. 3 c.1) specified that the right to vote was restricted to white males, although a few coloureds were privileged with the franchise by special Bill (Wood, 1990). This restriction was not abrogated until 1833, with the passing of $4 \mathrm{Wm} .4 \mathrm{c.} .1$ (an Act to relieve His Majesty's Free Coloured and Black Subjects of the Bahama Islands from all Civil Disabilities). This was reinforced the next year by $5 \mathrm{Wm} .4 \mathrm{c.9}$, which declared coloured and black citizens were "to have and enjoy all the rights, privileges and immunities whatsoever, to which they would have been entitled, if born of, and descended from, white ancestors" (Laws of The Bahamas, 1843). From that time, all free Bahamian males, regardless of skin colour, would have the right to vote if they satisfied the other qualifications specified in the 1807 Act. Obviously, after the 1833 Abolition Act there was a much larger number of free coloured and black Bahamians.

The 1807 Act had also specified that only a "white male inhabitant" could become a candidate for election to the House of Assembly. The above Acts similarly removed the colour restrictions in this regard. Common qualifications for attainment of political office then applied to all males: ownership of property, clear of all judgements and mortgages, to the value of at least one thousand pounds (later reduced to five hundred pounds), or proprietorship of at least fifty acres of land under cultivation and free of all legal encumbrances. The property qualifications, however, meant few coloured and black Bahamians would be wealthy enough to aspire to political office immediately after Emancipation.

Nevertheless, four coloured candidates were soon elected to the House. In December of 1833 Stephen Dillet was returned as one of the members for the Town District of Nassau and 
John Dean for the Western District. Samuel Minns was returned for Andros in August of the next year and Edward Laroda joined them in 1836 as the representative of Exuma (Election Book $1808-1868$, n.d.).

Stephen Dillet was the son of Etienne Dillet, a French officer, and Mary Catherine Esther Argo, a Haitian. Fleeing from Haiti in 1802, he and his mother were seized by a British privateer and brought to The Bahamas, where Stephen became a successful tailor (Baptism Record of Christ Church 1802-1828, p.169). He owned a small number of slaves between the early 1820 s and 1834 and was buying from and selling to prominent white Bahamians (Returns of Registrations of Slaves, 1822-1834). He took an active part in politics during the Governorship of the Abolitionist Sir James Carmichael Smyth (1829-1831), who was endeavouring to extend privileges to the coloured class. Presumably Dillet developed a taste for politics and took the first opportunity to stand for election to the Assembly. For Dillet and his fellow coloured members to have been elected so soon after the removal of restrictions indicates their social prominence and some degree of prosperity. John Patrick Dean was a butcher and he also owned slaves, ten by 1831 (Baptism Register of Christ Church 1802-1828, p.176; Returns of Registrations of Slaves, 1822-1834). Samuel Minns was an attorney. Edward Laroda was Stephen Dillet's brother. Little is known of Dean, Minns and Laroda.

The newly elected coloured members were well regarded by Charles R. Nesbitt, the English Deputy Colonial Secretary of the Bahamas, who commented in 1834 on their "decorous and gentlemanly behaviour, practical usefulness, and high-minded sense of duty." He added: "No rational person will now question the competency of free persons of colour to exercise their inalienable rights as British subjects, on account of the colour of their skin, or of their servile origin" (cited in Boyd, 1834, pp. vi-vii). The voting record shows Dillet, Minns and Laroda were particularly supportive of Government policies. Since the Opposition of the 1830s was largely composed of former slave-owners who had not come to terms with the reconstructed society and tried to impede the 'improvement' measures of the Governor, it would seem logical to expect the coloured members to back the Government.

Stephen Dillet's loyalty was recognised by appointment to various Government offices. In 1840 he was appointed Coroner of New Providence, in 1846 Postmaster and in 1850 Police Inspector. Governor George Mathew described Dillet as "one of the most respectable persons of color in this colony" and stated he "bears the highest character" (Mathew, 1846). On his appointment as Police Inspector Governor John Gregory described him as "one of our very best public servants" and he commented the appointment had "given universal satisfaction to the community, by whom he is held in great respect" (Gregory, 1851). Dillet also served as a Justice of the Peace and Director of the Public Bank. He was obviously an exceptional man and the Nassau Guardian (1880) paid tribute to him after his death as "a gentleman of polished manners" who "united with urbanity a strict integrity. Painstaking and honorable in business transactions, whatever he undertook was done well, and he felt a pride in doing his duty." 


\section{COLOURED LOYALTY TO THE ESTAWLISWYINT IN THE MID-NINETEENTH CENTURY}

Another coloured attorney, Thomas M. Mathews, won one of the seats for the Town District of Nassau in 1846 and Henry Stevenson, a coloured businessman, took the Andros seat in 1849 (Election Book 1808-1868, n.d. and Votes of the House of Assembly 1848-1852, n.d., p.12).

Henry Stevenson was the son of Jessamyn Thompson, a free coloured woman, and Henry Stevenson, Sr. In 1835 he married Christina Farquharson, youngest daughter of Charles Farquharson, the San Salvador planter. She was also coloured (Baptism Records of Christ Church 1802-1828, p.87). The introduction to the O'Brien Family Papers states that very little is known of the Stevenson side of the Family. A memorial to Henry Stevenson is to be found on the wall in St. Andrew's Kirk.

Thomas Mathews, like Stephen Dillet, was a loyal Government man and was awarded by public appointments. In 1849 he was made a Notary Public and in May 1850 he was appointed to the Executive Council, making him the first coloured man to hold such a position. He was at this time acting Attorney General and Governor John Gregory considered he had "every reason to think highly of him" (Gregory, 1850). He joined the Board of Public Health and later became a Justice of the Peace and trustee of the Public Library. Mathews resigned from the House in 1858 and two weeks later from the Executive Committee (along with two other members). He had clashed with Governor Charles Bayley over the amount of independence a Council member should enjoy. He never took part in factious opposition to the Government but felt he should "be allowed to exercise the fullest freedom of thought, and of action, in reference to measures brought forward either in the Council, or in the popular branch of the Legislature" (Mathews, 1858). This was a problematic area: should unofficial members, on principle, support bills in the House, whose drafts were discussed in Council and which were desired by the Government? Mathews was not the first to dispute the ambiguous role unofficial members filled and would not be the last.

Mathews did not find this quarrel ended his Government career. He continued acting in judicial posts (five times as Attorney General and three times Chief Justice). Ten years later he returned to the House of Assembly to assist the Establishment. A prominent Anglican, he was re-elected for the Town District in the turbulent election of 1868, defeating two Wesleyan Opposition candidates of the Disendowment or Reform Party. One of the defeated candidates was Robert H. Sawyer, who had introduced the Disendowment Bill into the House. This was a tactical maneuver on the part of the Church or Government Party, part of an unsuccessful effort to prevent the Disestablishment of the Anglican Church in The Bahamas. Mathews only remained temporarily in the House, but in 1876 he was appointed to the Legislative Council. Governor William Robinson wanted to reward Mathews for past services and was keen to add loyal Church men to the Councils (Robinson, 1876). He continued to serve in the Legislative Council until his retirement in 1885.

Stephen Dillet's son, Thomas William Henry Dillet, joined his father in the House in 1856. First he represented Exuma; he switched to the Western District of New Providence in the 
following year and, finally, in 1860 he won the Abaco seat. Thomas Dillet was educated at the King's College School in London; he studied law with Thomas Mathews and entered the Middle Temple for his Bar studies. This is an impressive curriculum vitae for the son of a coloured Bahamian tailor and some indication of his father's prosperity and ambition. He had been appointed a Notary Public in the 1840 s by Governor George Mathew, but had been suspended from that office by the same Governor, who had become paranoid in his distrust of local office holders during his long dispute with Archdeacon Trew. Governor Mathew was relieved of his post by the Secretary of State and Thomas Dillet was reinstated. Governor John Gregory believed the charge made by his predecessor unfair and "very revolting" and supported Dillet's efforts to obtain Government employment. He had high hopes for him but did emphasise in correspondence that he was "a Man of Colour" (his emphasis) (Gregory, 1850). One cannot tell if the skin colour made any difference to Dillet's chances, which did not yet get realised; the Colonial Office did have a large number of applicants for its patronage. Thomas Dillet became Editor of the Bahama Herald and the Secretary of the School Board. In 1864 he was at last appointed as acting Assistant Justice. Charles Nesbitt, now Colonial Secretary and Administrator in the absence of the Governor, noted that Thomas Dillet "by his urbanity and tact has surmounted the prejudice of colour and associates freely with the elite of this place" Nesbitt, 1864). An Englishman was appointed to the Assistant Justiceship in June 1866, but Governor Rawson Rawson persuaded Thomas Dillet to take a seat in the Legislative Council. Dillet was still keen to pursue a professional career in Government service and the Governor was ever supportive, giving him three months' leave to present his case to the Colonial Office in London. Rawson pressed his claims to the Secretary of State, "looking to the considerate manner in which Mr. Dillet has acted towards this Government with reference to this office - to the praiseworthy performance of his duties - and to the pecuniary sacrifice which he has been called upon to make, and the very serious disadvantages under which he would return to the bar of this Colony" (Governor's Dispatches, 1866, pp.451-452). Fortunately for the Governor, Dillet came back to The Bahamas without an appointment, for he was to prove a useful member of the Legislative Council in 1868 during the battle to disendow the Anglican Church. The Dillets were prominent members of Christ Church and thus Thomas would oppose the Opposition Bill in Council (Votes of House of Assembly, 1868, p.39). The advent of Governor James Walker led to a 'parley' and a compromise with the Opposition, although Dillet continued to vote against the bill, loyal to Church principles. In 1869 Dillet left The Bahamas for British Honduras, where he was appointed Clerk of the Courts and Keeper of the Records.

Another coloured Church Party man had arrived in the Assembly just prior to the Disendowment episode. In 1864 William Edward Armbrister was elected for Cat Island. He was the son of a Loyalist, John Armbrister Jr., who had left St. Augustine, Florida, to begin a business (a general store) in Nassau. He had later started a plantation in Cat Island in the early years of the nineteenth century. William was the son of Caroline Thurston, John's coloured second wife, who managed the business on Cat Island after her husband's death in 1828 (Register of Slaves, 1822, p.932; Baptism Register of Christ Church 1802-1828, p.119; Riley, 1980). William set himself up in a successful dry goods store in Nassau and he became a cultivator of pineapples and sisal in Cat Island. After his election to the House, W.E. Armbrister was to prove a useful Government supporter throughout his parliamentary career. 
In the 1870 s it remained the case that "political differences are so mixed up with and so dependent upon religious or denominational views" (Robinson, 1875). Govemor William Robinson was experiencing difficulties controlling his Executive Council, particularly two senior Wesleyan members of the House, R.H. Sawyer and Dr. Kemp. This is probably the motive behind his appointment of W.E. Armbrister, an Anglican, to the Executive Council in 1875. Armbrister was a Vestryman for over fifty years, the first commissioner for Christ Church when it was made a cathedral and a representative in the Synod from its formation up to 1904 . He was also a committee member of The Bahamas Church Aid Society and the treasurer of The Bahamas Auxiliary Bible Society (Report of the Proceedings of the $13^{\text {th }}$ Synod of the Church in the Diocese of Nassau, 1888, p.6; Nassau Guardian, 1907; Bahamas Almanac and Register, 1857, p.45; Bahamas Almanac and Directory, 1879, p.38). Armbrister was truly a pillar of the Anglican community and his presence on the Executive Council would help to restore its balance.

In 1887 W.E. Armbrister retired to the Legislative Council, one of only two unofficial members to serve on both councils (the other being Dr. Kemp). The Governor noted that he had "always been a warm supporter of the government" (Blake, 1887). He was made President of the Legislative Council in 1901. Armbrister sat on the Board of Public Works for thirty-four years; he was Chairman of the Commissioners of the New Providence Asylum for seven years and he was one of the directors of the Nassau Fire and Marine Insurance Company. On his death, at the age of 88, the Nassau Guardian (1907) noted he was known for his "sterling upright character and his cheerful and genial disposition and his genuine humble-mindedness". However, a comment from William Parliament Adderley, a black Member of the Assembly, indicated that non-whites did not regard Armbrister as their representative. Adderley, on a visit to the Colonial Office in London in 1904, complained the 'people of colour' had no representation on either Councils. He emphasised that he did not count Armbrister (Fiddian, 1904). On the other hand, Armbrister managed to satisfy both the Government and the white elite. A photograph of him shows that he could easily 'pass' and it does seem that it was generally forgotten that he was coloured. Such an instance was when Governor Shea requested alterations in the Royal Instructions simply because he was uncomfortable at the presence of the acting Receiver General, a coloured man, when race entered the Council discussions. The British Government refused this request, one Colonial Officer commenting: "Nor is there much hope for us in the West Indies if we cannot fairly take the advice and opinion of those coloured people who are rising in the social scale. The fact is in The Bahamas the race jealousy has been allowed to become very accentuated" (Colonial Office Dispatch, 1888). Notably, W.E. Armbrister's presence in the Council did not cause any embarrassment. He seemed to have mixed easily with white Nassau society and, a long time widowed, he married the daughter of the late Bryon Bode, white merchant and former House member.

\section{A MORE RADICAL POLITICIAN - JAMES CARMICHAEL SMITH}

In the 1882 election three coloured members were returned - W.E. Armbrister, George A. McGregor, Resident Justice at Inagua, and James Carmichael Smith, elected for the Western District. James Carmichael Smith, presumably named in honour of the Abolitionist Governor of the $1820 \mathrm{~s} / 1830 \mathrm{~s}$, was the son of a Yorkshire man and a coloured woman. His father apparently made money during the Blockade-running era. He was educated at the Boys Central School and 
the Nassau Anglican Grammar School and afterwards went to sea for four and half years, visiting Australia and China.

Smith comes across as an intelligent man, dedicated to the fight for justice for the coloured and black classes and committed to the economic improvement of his country. His views particularly come across in the newspaper articles he wrote in 1886 in reply to the comments of James Gardiner, an English scientist working on a government-sponsored study (Nassau Guardian, 1886). Smith emphasised the deleterious effects of the 'metayer system' in retarding improvement and advocated peasant proprietary, alongside larger-scale capitalist farming. Gardiner and Smith bandied ideas and did not disagree about the problems of sharecropping and benefits of ownership. However, they differed over the amount of investment capital available in The Bahamas and over Gardiner's remarks that the black population bore some blame for the lack of economic improvement through laziness and lack of energy. Although Gardiner claimed lack of race prejudice in that he largely blamed the white Bahamians for the state of affairs, he expressed the standard Victorian Englishman's view of the African: lazy, unmotivated, needing guidance and protection. Significantly, Smith's reaction and the views he articulated show, for once, identity with the African by an influential mulatto and race pride alongside patriotism. His solutions to the economic problems of the Colony included changes in land tenure and improved public education, particularly more vocational training.

One of Gardiner's observations is key: Smith "has many enemies in Nassau" (Nassau Guardian, 6 November 1886). At this early date, though, the Nassau elite could tolerate him, presumably because he could not actually pose a threat to them as yet. Smith, also, did not, in principle, oppose colonial government either. He mentioned in his articles that he was a Monarchist by conviction and loyal to the British Government. In The Bahamas' situation, Smith would have likely seen more immediate danger in government by an Assembly controlled by the merchant oligarchy than the paternalistic hand of the British Government. Essentially James Smith acted as conscience guided him. That might entail supporting the Government, or going against it, depending on the circumstances. When Smith spoke and voted against the Governor in 1886, despite Blake's assertion that this was usual, this was not a matter of policy, simply a matter of an independent member voting as he saw fit (Blake, 1886). Besides, Smith did earn his livelihood in government offices, first as a clerk and storekeeper in the Commissariat Department and then as Postmaster.

James C. Smith was much more radical and outspoken than previous coloured members of the House. But an individual member could achieve little. Those regularly opposing the Government were the white Wesleyans, whose interests were in many ways opposed to those of the black and coloured population. James Smith did occasionally join with the Wesleyans to oppose the Government. This was evident, for example when they attempted to prevent local hotel owners from selling spirits to non-residents. However, these were minor issues and this was not an alliance that Smith probably found too palatable. Smith's two coloured colleagues were of little assistance. W.E. Armbrister was the quintessential 'government man' and had no interest in leading any group fighting for the rights of the non-white population. George McGregor was a resident justice, so had to observe caution in his Legislative behaviour. 
James C. Smith did introduce a bill in 1885 to regulate the payment of advances and shares to masters and seamen of vessels engaged in sponge fishing, which was very much in the interests of the spongers in the face of their continued debt to the Nassau merchants. He also amended the bill at the third reading to include the obligation of the owner or agent to produce a complete copy of account sales and a detailed statement showing the division of the net proceeds. This 1887 amendment was an important innovation in the system, offering some protection to spongers.

James Smith was a very active House member, serving on numerous committees, some concerned with issues important to the disadvantaged, such as medical relief for the poor, tariff reform, extension of the operations of savings banks and reform of the electoral law. Groups of citizens often requested Smith to present their petitions to the House; typical was the one from the pilots of Nassau to improve conditions and rates (Votes of the House of Assembly, 1887, pp.79-80).

As might be expected, Smith was returned again in 1889, as was McGregor. Joseph Dupuch made his return for the Eastern District. ${ }^{\text {l }}$ William Campbell Adderley, a black Bahamian elected for the Town District, J.W.H. Deveaux, for Cat Island, and George R. Evans for Andros, joined them. Governor Shea (1889) commented on this increase in coloured members and stated "the fact has little significance as the question of race or colour was scarcely heard of'. He added that this representation "tends to gratify a popular sentiment, while the presence of those coloured men in the Assembly will not be the cause of any inconvenience". This is acknowledgement of the conservative politics of the coloured members to date, even of James C. Smith, who could be annoying sometimes but scarcely threatening. The race question was assiduously swept under the carpet by the Government anyway, as Powles found to his cost when he had attempted to dispense equal justice in The Bahamas. He had lost the support of Governor Blake because he brought to the fore 'the colour question' (Themistocleous, 1997). The fact that Governor Shea saw the election of such men as a safety valve is telling.

James Carmichael Smith continued to be the most forthright of the non-white members, but an unfortunate 'affair' effectively silenced him at the beginning of the 1890s. Whether Smith was cleverly sidelined by the 'Nassau oligarchy' or simply preoccupied by the procedures taken by an irate father trying to exact revenge for the sake of his daughter and family name is a matter of speculation. Stephen Albert Dillet brought charges of seduction and abduction of his daughter, Elizabeth, against Smith. Thwarted in his legal proceedings by his daughter's flight from The Bahamas, Dillet requested an enquiry by the Governor in Council, since Smith was a Government employee. After surveying the evidence supplied by Dillet, Governor Shea decided there was a case to answer and an enquiry was held by him in 1893. Smith was found guilty and suspended from office as Postmaster. Smith decided to appeal the Decision to the Privy Council and went to England. The Secretary of State acquitted and exonerated Smith from the charges after hearing Elizabeth Dillet's statement. All this took time and energy and when he returned to Nassau he did not seem to have the same intensity or force. He was not such a presence in the House, although returned by the voters in 1896. The Colonial Office offered him an appointment as assistant Postmaster in Freetown, Sierra Leone, which he accepted. 


\section{CONCLUSION}

The coloured members of the Bahamian House of Assembly exhibited many of the characteristics of the West Indian middle class. They had either managed to get a good education for themselves or secured one for their sons; they attained good jobs, often in law or the civil service, or they owned businesses and sent their sons in to the professions; they attended the right churches, usually Christ Church, the church (after 1861 cathedral) favoured by the Governor and the English residents, or St. Andrew's Kirk. They were respected, in different ways, by white and non-white. They emulated the whites and a recognised position in society was their goal. Generally, they would not have been socially welcomed into the homes of white Bahamians, no matter how respected. Such as W.E. Armbrister were exceptional. On the other hand, they did not normally mix with black Bahamians; racism worked both ways. There was social mixing on the committees of charities and public institutions and at the prestigious Masonic Lodge in which Stephen Dillet, Thomas Dillet, Edward Laroda and Joseph Dupuch were all inducted, alongside high-standing white Bahamians.

Politically the coloured members did not pose any threat, certainly not to the Governor and colonial government, of whom they were generally supportive, nor to the white oligarchy, being too few in number and lacking even a vague notion of 'party' organisation or ties. Only James Carmichael Smith could be viewed as irksome; he followed too independent a line. However, he could be maneuvered out, given the right opportunity and an amenable Governor. These representatives were, for the most part, conservative and personally ambitious. They were aiming to climb upwards socially and economically; a political career was a step in the right direction. A seat on a Council or even a Board was a power base, being used to the full at the end of the century by a group of whites to further cement their powerful position. The coloured members simply wanted to do the same.

\section{NOTES}

1. The word "coloured" in this paper is used to denote a person of mixed blood.

2. Joseph Dupuch had been elected in 1875 , but had lost his seat in 1882 . He was the son of Elias Dupuch, a Frenchman, who had migrated to Nassau in 1840 and started a foundry. He soon prospered and owned a large property on Bay Street. His son, Joseph, was coloured. See Dupuch, E. (1967, p.19 and inset picture). Joseph was already a successful businessman in the sponging and building industries, when he inherited the entire estate of his father, who died intestate (Dupuch, p.30). Joseph was Grand Master of the Royal Victoria Lodge and built the Masonic Temple. 


\section{REFERENCES}

(Editor's note: Owing to the extensive use of archival sources for this article, references are given in three separate lists. This is a departure from the normal referencing style of the journal.)

\section{Primary Sources-Manuseripts}

Baptism register of Christ Church 1802-1828.

Blake, H. (1886, May 22). Original correspondence from the Governor to the Secretary of State, C.0.23/228/148-156.

Blake, H. (1887, July 9). Original correspondence from the Governor to the Secretary of State, no. 90, C. $0.23 / 229 / 353$.

Colonial Office dispatch no. 24542. (1888, December 11). C.0.23/230/433.

Dillet, S.A. (1892, May 18). Private correspondence to J.C. Smith, C.O.23/236/321.

Election book 1808-1868.

Fiddian, A. (1904, September 26). Memorandum of interview, C.0.23/259/581.

Gregory, J. (1850, April 18). Private correspondence to the Undersecretary at the Colonial Office, C.0.23/135/15-17.

Gregory, J. (1850, May 30). Original correspondence from the Governor to the Secretary of State, no.48, C.0.23/135/249-251.

Gregory, J. (1851, June 20). Original correspondence from the Governor to the Secretary of State, no. 46, C.0.23/138/386-389.

Mathew, G. (1846, March 12). Original correspondence from the Governor to the Secretary of State, no. 20, C.0.23/123/151.

Mathews, T.M. (1858, March). Private correspondence to the Governor, C.0.23/156/193-197.

Nesbitt, C.R. (1864, June 8). Original correspondence from the Governor to the Secretary of State, no. 3, C.O.23/175/10-11.

O'Brien family papers 1801-1937.

Pollen, C.H. (1893). Character reference, C.0.23/238/293-294.

Powles, L.D. (1893, July 31). Private correspondence to Undersecretary at the Colonial Office, C.0.23/238/278-286. 
Rawson, R. (1866, July 21). Governor's Despatch, no.125, pp. 451-452.

Return of Registration of Sloves, 1822-1834.

Robinson, W. (1875, June 24). Original correspondence from the Governor to the Secretary of State, C.O.23/214/148-153.

Robinson, W. (1876, June 17). Governor's Despatch, no. 105, p. 514.

Shea, A. (1889, July 2). Original correspondence from the Governor to the Secretary of State, C.0.23/231/356-357.

Shea A. (1893, April 29). Original correspondence from the Governor to the Secretary of State, C.0.23/236/256-262 and enclosures C.0.23/236/264-397.

Smith, J.C. (1892, May 18). Private correspondence to S.A. Dillet, C.0.23/236/321.

\section{Primary Sources - Printed}

Bahamas Almanac and Directory. (1879).

Bahamas Almanac and Register. (1857).

Laws of The Bahamas. (1843). Nassau, Bahamas.

Nassau Guardian. (25 September through 10 November 1886).

Nesbitt, C.R. (1834). Preface. In J. Boyd, The vision, and other poems, in blank verse (pp.vi-vii). London: Longman \& Co.

Obituary of Stephen Dillet. (1880, October 9). Nassau Guardian.

Obituary of W.E. Armbrister. (1907, June 22). _Nassau Guardian. June).

Report of the proceedings of the $13^{\text {th }}$ synod of the Church in the diocese of Nassau. (1888,

Votes of the House of Assembly 1848-1852, n.d.

Votes of the House of Assembly 1868,-n.d.

Votes of the House of Assembly 1887, n.d.

\section{Secondary Sources}

Dupuch, E. (1967). Tribune story. London: Ernest Benn. 
McWeeney, S. (1994). The 'Haitian Problem' in The Bahamas at the close of the $18^{\text {th }}$ century. Journal of the Bahamas Historical Society, 16, 7.

Powles, L.D. (1888). Land of the pink pearl. London: Sampson Low, Marston, Searle \& Rivington.

Riley, S. (1980). W.E. Armbrister's Loyalist heritage. Journal of the Bahamas Historical Society, 2, 3-10.

Saunders, D.G. (1990). Bahamian society after Emancipation. Kingston: Ian Randle.

Smith, R. T. (1988). Kinship and class in the West Indies: a genealogical study of Jamaica and Guyana. Cambridge: Cambridge University Press.

Themistocleous, R.M. (1997). L.D. Powles, stipendiary magistrate. Journal of the Bahamas Historical Society, 19, 19-29.

Wood, D. (1990). The free people of colour in Bahamian society. Journal of the Bahamas Historical Society, 12, 20-24. 